\title{
The impact of Crossrail on the retail property sector
}

Received 21 March 2005

\section{Bob Thompson}

is Director of the RETRI Group, established in 2001 as a specialist real estate research boutique. He is a past President of the European Real Estate Society, a visiting research fellow at Reading University and a senior research associate at the College of Estate Management.

\begin{abstract}
This paper looks at the potential impacts of Crossrail upon the retail sector along the route of Line 1 . It establishes a retail hierarchy of locations along the route, and looks at the interactions that may exist within that structure. The paper identifies the sources of retail demand and its characteristics, in particular its propensity for mobility from centre to centre. Drilling down, the paper identifies specific locations that will see a negative impact during the construction phases of the project, and the opportunities that may arise as a result of the redevelopment.
\end{abstract}

\section{Keywords:}

retail impact, development opportunities, expenditure mobility, visitor expenditure, workforce expenditure, Crossrail, London

\section{INTRODUCTION}

It is safe to say that the construction of any new transport infrastructure has an impact upon the property markets through which it runs. This impact may be seen in improved access, allowing greater throughput of goods or people; it may be seen in facilitation of facilities that were otherwise unavailable - for example, by servicing new areas of land; or the new infrastructure may add stimulus to the redevelopment of existing facilities that were otherwise mundane. Equally there may be negative impacts, through blight on the markets through which it runs during the construction period or through the compulsory purchase of private sector assets.

The main yardstick by which the impact of transport infrastructure is assessed is value. For example, research by Jones Lang LaSalle (JLL) on behalf of Transport for London ${ }^{1}$ found that the impact of the Jubilee Line extension (JLE) at Canary Wharf had been in the range of $£ 755 \mathrm{~m}$ to $£ 1.9 \mathrm{bn}$.

This paper looks at the potential impact of the development upon retail property along the route of Crossrail, and in particular the impact on value. Given the uncertainty that still besets the project, only the first phase - known as Line 1 - is examined. 


\section{Congestion on the network carries an economic cost}

\section{Crossrail provides a seven per cent increase in capacity}

\section{CROSSRAIL}

On the basis of its projected costs of approximately $£ 10 \mathrm{bn}$, Crossrail probably will be the largest infrastructure project ever undertaken in the UK.

Proposals for the construction of a new east-west rail link across London were first mooted shortly after the Second World War. The original Crossrail scheme was first proposed in 1989; it was forced on to the political agenda as a result of campaigns by business and transport groups, only to be shelved again when successive transport secretaries were daunted by its cost and complexity.

When the Crossrail scheme was first contemplated it focused on addressing the problems of central London. In its latest incarnation, the issues that it seeks to address have a wider spatial impact.

London is expanding through regeneration in the east, and its enlarged job catchment area requires the provision of efficient and reliable travel across a wide geographical area. Additionally the government's recent Sustainable Communities Plan will place significant additional demands on public transport. Crossrail would contribute to meeting these demands.

The business case for Crossrail is based on the fact that current rail commuter services into London and on the London Underground network have high levels of overcrowding, particularly through central London. Many parts of the London Underground network carry passenger flows well above their planned capacity. This congestion carries an economic cost.

Crossrail would make a significant contribution to improving services to London's travelling public by addressing existing and future overcrowding on both the main rail and London Underground networks, providing about a 7 per cent increase of current capacity across the central area.

Additionally, because Crossrail would substantially improve accessibility and travel times between key destinations, the business plan suggests that it would bring wider benefits and help delivery of other government initiatives, including contributing to the government's transport and planning policies and supporting the further development of London's financial and business services sector.

Crossrail will consist of new rail tunnels running west-east through central London, connecting directly with existing surface rail routes to Maidenhead and Heathrow in the west and Shenfield and Abbey Wood in the east. By connecting the major London rail terminals of Paddington and Liverpool Street, Crossrail will enable interconnecting mainline train services to cross the centre of London via a number of new purpose-built stations.

The central section of Crossrail is a twin-bore tunnel running deep under the centre of the capital. It runs from Paddington in the west to Whitechapel in the east via Tottenham Court Road, Farringdon and Liverpool Street. 


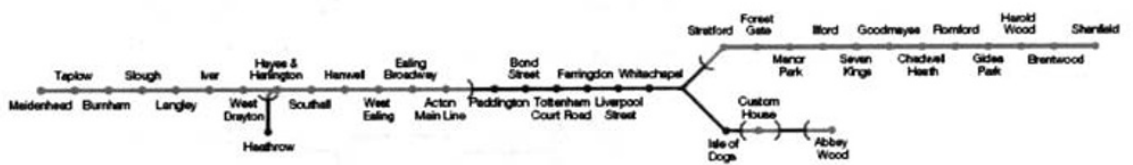

Figure 1: Crossrail Lıne 1 route

At its westernmost end services would continue to either Maidenhead or Heathrow. To the east, the line splits, one branch going to Shenfield in Essex and the other running via Docklands and Woolwich to Abbey Wood (Figure 1).

At peak times, between 7am and 10am, 364,000 people are forecast to use the service from Shenfield to Stratford, while 24,500 will use the central section between Farringdon and Tottenham Court Road.

The tentative completion date for the entire project has been set by Cross London Rail Links, the developer of the project, at 2013.

\section{RETAILING ALONG THE ROUTE}

The Crossrail route passes through all levels of the retail hierarchy. At the highest level the West End of London is a regional shopping centre with a high proportion of comparison shopping. Along the route are local comparison centres such as Slough and Romford. Finally there are local, mainly convenience, facilities such as Shenfield and Southall.

Figure 2 shows the relative sizes of the main comparison centres

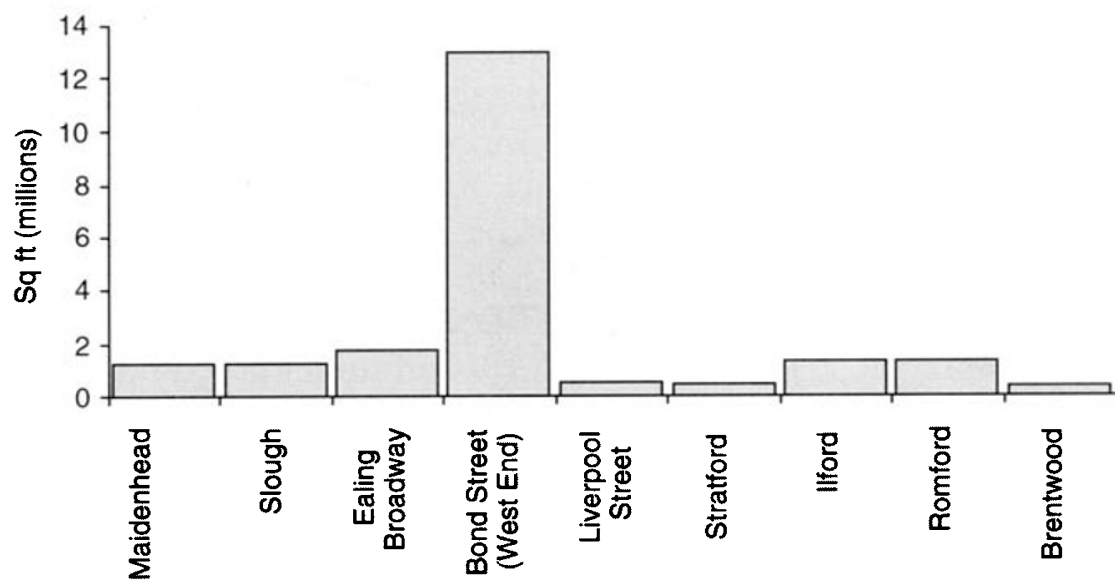

Source: ODPM

Figure 2: Crossrail - Comparison centres by retail stock size 


\section{Retailers see little benefit from Crossrail}

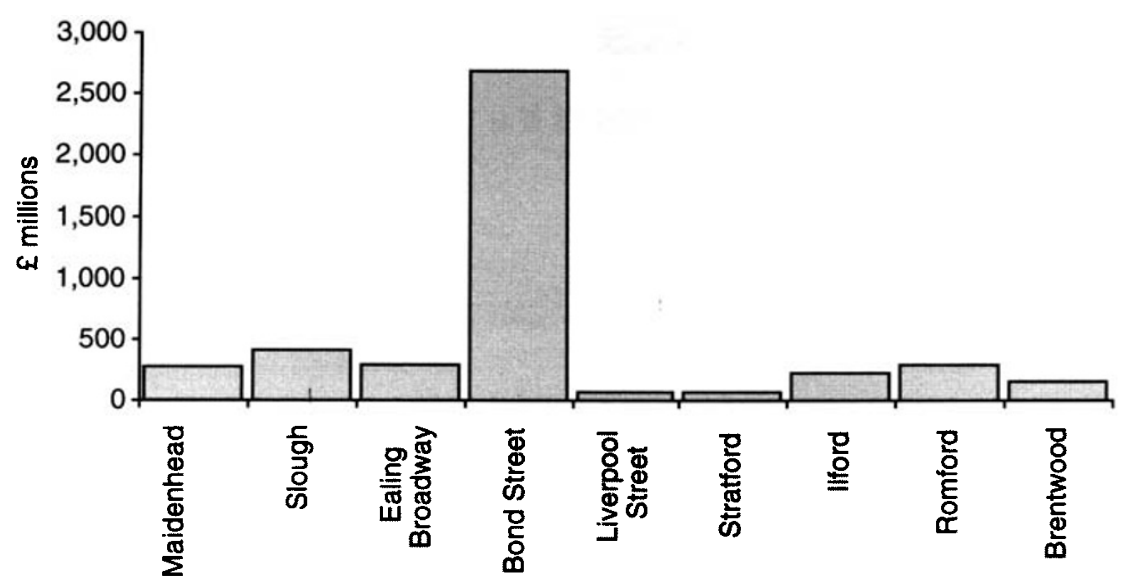

Source: Experian

Figure 3: Comparison expenditure

along the route. Purists will note the absence of the substantial retail facilities at Canary Wharf. This development has been omitted for a number of reasons. First, despite its size, it serves mainly the workforce at Canary Wharf; secondly its focus is on convenience spending; and thirdly the Crossrail Isle of Dogs station will be some way away from the shopping centre under Canada Square.

The stock shown is dominated by the provision in the West End, through the heart of which runs Crossrail. Maidenhead, Slough and Ealing Broadway all serve a substantial local catchment area, as do the centres to the east at Ilford, Romford and Brentwood. The oddity here is Stratford, which despite being at the heart of the regeneration efforts in east London and already being one of the best connected stations in London, has a relatively low level of comparison retail relative to its catchment area. Interestingly, and totally independent of Crossrail, this shortfall will be addressed by the Stratford City scheme which, among other things, will bring an additional 1.6 million square feet of retail space.

Figure 3 shows the same locations in terms of comparison expenditure, and a similar pattern can be seen with the West End dominating.

\section{EXPECTATION}

Building Crossrail would benefit the UK economy by $£ 19$ bn over a 30-year period, studies for the Mayor of London ${ }^{2}$ have concluded. The $£ 19$ bn benefit would divide three ways - $£ 8$ bn from output associated with people able to access central London more easily, $£ 3$ bn from additional output and $£ 8 b$ from journey time savings.

As far as retailers are concerned, little benefit is expected from Crossrail. According to the British Retail Consortium, retailers would pay a disproportionate cost (in terms of increased local 


\section{The Jubilee Line extension increased accessibility - Crossrail increases capacity}

taxation) for little or no direct benefit, ${ }^{3}$ but since most mainstream retail property is leased, retailers do not necessarily see an increase in property value as germane to their business.

The JLL Jubilee Line research ${ }^{4}$ started out with two basic hypotheses:

- that improved perceived accessibility should result in increased value, other things being equal

- that those areas where the line made the greatest incremental change to perceived accessibility would be expected to show a greater change than those where the JLE was simply adding to an area already perceived to be relatively well served.

But there is a key difference between Crossrail and the JLE. Crossrail, with the exception of the south-eastern fork to Abbey Wood, uses stations that are already well served with rail transport. The JLE opened up new areas south of the Thames and in Docklands, linking them to the central core. The JLE was about creating a new line; primarily Crossrail is about adding capacity to existing routes. Any expectation of increased value is therefore limited.

\section{RETAIL IMPACT}

Crossrail will impact on retail in three main ways.

- During the construction phase it will inevitably blight some retailing.

- The construction phase itself will offer up some development opportunities.

- The increased capacity and reduced travel times will make consumer expenditure more mobile.

\section{Blight}

Inevitably, building Crossrail will disrupt property and business activity in central London. Approximately 3,500 properties have been identified for temporary use or permanent acquisition. The vast majority of the route is underground, thus only the corridor of land occupied by and around the tunnels would be acquired.

Twenty-two kilometres of tunnels would be constructed between Paddington and Liverpool Street. In these cases, where there is generally no disturbance of the surface, the impact on owners and occupiers is likely to be minimal. But there are over 300 properties above ground where construction of Crossrail would require the acquisition of surface land and buildings, to enable the construction of stations, entrances, vent shafts, depots and stabling.

The following are likely to be among the worst-affected retail areas during the construction phase.

- Brick Lane. Hanbury Street, in the heart of the Spitalfields conservation area, will provide the starting point for the tunnel- 
The western side of Hanover Square may be closed for five years

\section{Increased retail opportunities arise along the southern fringe of Oxford Street}

boring machines. This is likely to have an impact on the retail offer in Brick Lane and at the old Truman Brewery.

- Oxford Street/South Molton Street. The construction of the operations centre and western ticket hall adjacent to the West One shopping centre is likely to have an impact on retailing in Oxford and South Molton Streets. The western side of Hanover Square Gardens will be closed for a period while works relating to the eastern ticket hall are undertaken. The construction, including fit-out and commissioning, of the station at Bond Street will be undertaken over a period of about five years.

- Oxford Street/Charing Cross Road. Tottenham Court Road station will be located between Great Chapel Street and Charing Cross Road, to the south of Oxford Street. Two new ticket halls will be constructed, one at Dean Street and the other beneath the plaza at the front of Centre Point. Buildings will be demolished at Dean Street, Fareham Street, Oxford Street/ Charing Cross Road, Goslett Yard and Fisher Street. Again, retailing in Oxford Street will be affected.

\section{Development opportunities}

Development opportunities may arise around Crossrail stations indeed. this has been encouraged by the government as a means of funding the project. This may involve the permanent acquisition of space above stations.

No specific provision is included in the Crossrail bill for the replacement of buildings demolished in pursuit of the scheme. As it runs through one of the most valuable retail areas in the country and brings increased footfall and employment, it seems likely that redevelopment will increase retail opportunities, particularly along the southern fringe of Oxford Street.

\section{Expenditure mobility}

Notwithstanding the local impacts, there is a question about the impact of the development itself on overall demand for retail facilities along the route. Although, for the most part, Crossrail does not add any new accessibility, by increasing the capacity of the network and improving travel times it adds to the utility of the service. This increase in utility is described by reductions in travel time between the stations on the route. This paper will examine the interaction between Bond Street, representing the West End of London, and each of the comparison centres along the route.

Demand for retail facilities in all locations along the route will be seen from three groups of consumers:

- residents

- visitors

- the local workforce. 


\section{Increased employment will add slightly to expenditure in the West End}

The balance between these three groups will vary depending on the location. The West End sees demand mainly from domestic and foreign visitors and expenditure by the workforce, residents forming a relatively small part of the overall spend. Therefore the retail impact of Crossrail can be determined by the summation of the expenditure brought by the increased workforce and the increased expenditure from visitors generated by the increased utility of the service.

\section{Workforce expenditure}

The additional employment generated by Crossrail has been estimated at 18,000 by 2010.5 Half of this uplift is outside London, leaving 9,000 additional jobs across the whole of London. This figure is unattributable to individual locations. Nor is there any clear indication of per capita expenditure while in London.

By taking data from the Family Spending survey ${ }^{6}$ it is possible to pull out a subset of likely convenience spending that would include spending near the workplace. But in the absence of any empirical evidence, the proportion can only be decided arbitrarily.

At 25 per cent workplace spend the 9,000 jobs would deliver some $£ 1.6 \mathrm{~m}$ additional expenditure. At 75 per cent the figure rises to $£ 4.9 \mathrm{~m}$. Two points need to be made:

- these figures are trivial in the context of the $£ 2.7 \mathrm{bn}$ of comparison expenditure currently seen in the West End

- the 9,000 jobs are for London as a whole, not just the Crossrail corridor.

\section{Visitor expenditure}

Domestic visitors will include those visiting purely for shopping purposes, but the tourism data $^{7}$ categorise this more broadly as 'pleasure'. On that basis 14.3 million visitors came to London in 2003, 17 per cent (2.4 million) of them from the south-east. They spent just over $£ 1.5 \mathrm{bn}$ on shopping, eating and drinking. Thirtyseven per cent ( 5.3 million) of them came by train. Unfortunately, the data are silent as to how many visitors came to the West End by train to shop for goods, which makes it virtually impossible to build a generic model to assess how much impact a small increase in utility will have on retail demand in the West End.

Just how mobile is comparison expenditure? Research for the Newspaper Society ${ }^{8}$ stresses the importance of convenience in the choice of all shopping, not just food.

Figure 4 shows how intensely local retailing has become, with a proliferation of choice available within relatively short distances. Consistently, research by AC Nielsen ${ }^{9}$ shows that the most important reasons influencing people's choice of where to shop for food are: 


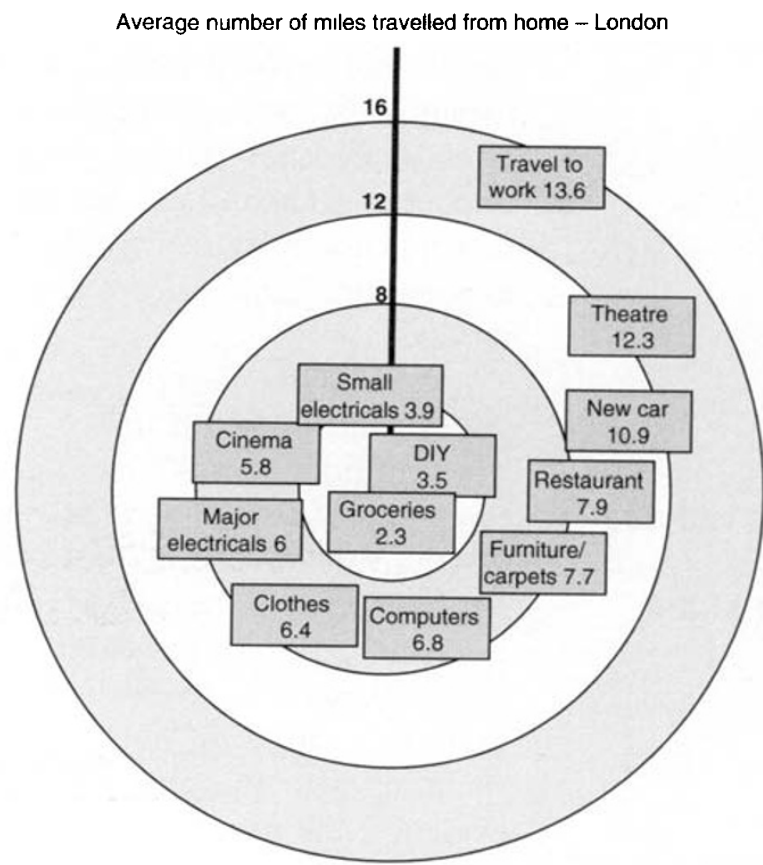

Source: The Future Foundation

Figure 4: Propensity to travel for shopping and leısure purposes

For the residents of Romford it is quicker to drive to Lakeside than take Crossrail to the West End
- quality, fresh foods, 17 per cent of households

- a convenient location, at 11 per cent of households.

This seems to be at odds with the success of large regional shopping centres that draw their catchment very widely. In fact the West End is a large regional centre, and competes with centres like Lakeside al Thurrock and Bluewater at Dartford rather than Ealing and Romford.

Table 1 shows an approximation of the impact of Crossrail on travel times. To the east of London, despite Crossrail cutting ten minutes off journey times, for the residents of Brentwood and Romford it is still quicker to drive to Lakeside rather than take Crossrail to the West End. For Ilford and Stratford the propositior

Table I: Relatıve journey tımes: shows an approximatıon of the ımpact of Crossrall on travel tımes.

\begin{tabular}{lllll}
\hline & $\begin{array}{l}\text { Journey time } \\
\text { to Bond Street }\end{array}$ & $\begin{array}{l}\text { Crossrail } \\
\text { saving }\end{array}$ & $\begin{array}{l}\text { Minutes } \\
\text { New } \\
\text { journey time }\end{array}$ & $\begin{array}{l}\text { Lakesid } \\
\text { by car }\end{array}$ \\
\hline Brentwood & 52 & 10 & 42 & 18 \\
Romford & 39 & 10 & 29 & 21 \\
Ilford & 28 & 10 & 18 & 29 \\
Stratford & 22 & 10 & 12 & 35 \\
Liverpool Street & 12 & 5 & 7 & 62 \\
Ealing Broadway & 41 & 10 & 31 & 63 \\
Slough & 50 & 10 & 40 & 59 \\
Maidenhead & 61 & 10 & 51 & \\
\hline
\end{tabular}


looks more compelling, especially given the paucity of retail facilities in Stratford. But factor in the development of Stratford City and the journey looks significantly less attractive. Only to the west of London does the West End become the regional shopping centre that is easiest to access.

\section{CONCLUSIONS}

The objective of this paper was to set up a model that would allow assessment of the impact of Crossrail upon the mobility of expenditure and thereby retail property values. This objective has not been met, largely through the unavailability of data at a sufficiently low level of detail to enable spatial differences to be established. Unless one understands the structure of existing demand for retailing it is not possible to model any changes to the infrastructure that sustains it.

Nevertheless it is possible to assert that Crossrail will improve the accessibility of the West End to its users, and as a consequence the expectation would be that demand for retail facilities will increase. But this is coloured by the fact that the increase in utility is small when set against the existing infrastructure, and evidence suggests that the comparison expenditure that would be affected is actually relatively local.

Any increase in jobs as a result of Crossrail will generate additional demand for convenience facilities particularly, although again the data are not specific enough to enable a great deal of quantification. The impact ranges between $£ 1.6 \mathrm{~m}$ and $£ 4.9 \mathrm{~m}$ per annum at current values.

There is likely to be a detrimental impact on the West End during the construction phase of Crossrail, with substantial temporary loss of amenity adjacent to the south side of Oxford Street. Similarly, the redevelopment of properties as a result of Crossrail will generate opportunities for retailing to spread slightly south of the existing facilities.

On balance this is an unsatisfactory result. In order better to quantify the impact on retail demand and thence value, further research is needed on the relationship between the different comparison centres along the Crossrail route. In particular empirical research is needed to identify the sources of expenditure in each location.

\section{References}

1 Jones Lang LaSalle (2004) Assessing the Change in Land and Property Values Attributable to the Jubilee Line Extension, Transport for London, London, UK.

2. Rosewell, B. (2004) The Case for Crossrail, GLA Economics, London, UK

3. Britısh Retall Consortium (2005) Crossral - The Retail Response, British Retail Consortium, London, UK.

4. Jones Lang LaSalle, ref. 1 above.

5 Centre for Economics and Business Research (1994) The Economic Impact of Crossral Phases One and Two, CEBR, London, UK. 
Five-yearly revaluation

\section{Collation and analysis of evidence}

The bill may then be adjusted to take account of transitional provisions that limit changes in the tax for any particular premises from one year to the next. This is where many of the complexities come into play.

The RV of a property is reviewed every five years. It is based on an estimate of the rental value of premises in the open market two years prior to the revaluation taking effect. Therefore the 2005 revaluation is based on the rental figures from 1 April 2003.

It is possible to appeal against the RV, which in the first instance is considered by the valuation officer (in England and Wales), or the assessor (in Scotland). If disputes cannot be resolved by negotiation they are then referred initially to the Valuation Tribunal and on further appeal to the Lands Tribunal. Appeals on points of law can go all the way to the House of Lords.

The UBR is simply the tax rate applied to the RV to produce the rate bill. Traditionally it is expressed as an amount payable for each pound of RV. England, Scotland and Wales each have their own separate arrangements, and in England and Scotland there is a slightly lower UBR for small businesses.

There is no appeal against the UBR, although rate demands can be challenged if they are wrongly served or contain errors in calculation.

The tax is collected by local councils, but is not used directly to pay for local services. Since the radical reform of the rating system in 1990, the income from rate bills is passed on to the Exchequer. The money is then redistributed between councils as part of the government support for local services. Thus, there is no direct link between the rates and the services provided by the council.

\section{RATEABLE VALUE}

The Valuation Office, an executive agency of the Inland Revenue, is responsible for assessing the RV of every commercial property in England and Wales. In Scotland the task is the responsibility of the Scottish assessors.

The valuation exercise begins about 30 months before the revaluation date by the collection of evidence. The Valuation Office sends out 'rent return' forms, which are similar to tax returns and require details of the rent paid and other lease terms. The information is then analysed to provide evidence from which the valuations can be calculated.

If the actual rent of a property was fixed close to the valuation date it will provide a strong indication of the level at which the RV should be determined. But the rent may need first to be adjusted for, inter alia, rent-free periods, premiums or reverse premiums, fitting-out expenditure, etc. There will also be differences between the terms of the actual lease and the hypothetical tenancy, which is to be assumed in the rating valuation, and these will have to be adjusted for prior to analysis. Rents that are close to the valuation 
6. Office for National Statistics (2003) Famlly Spending - A Report on the 20(1)2-20(1)3 Expendlture and Food Survey, ONS, London, UK.

7. UK tourism survey, avallable at staruk.org.

8 The Future Foundation (2000) The Renalssance of Regional Nations Local and Regional Identity in a Glohal W'orld. The Newspaper Society, London, UK

9. AC Nielsen (2003) Homescan Survey. AC Nielsen. Oxford. UK. 